\title{
Municipal solid waste characterization and management in Uyo, Akwa Ibom State, Nigeria
}

\author{
E. N. Okey ${ }^{1}$, E. J. Umana ${ }^{2}$, A. A. Markson ${ }^{2}$ \& P. A. Okey ${ }^{3}$ \\ ${ }^{1}$ Department of Biological Sciences, Akwa Ibom State University, Nigeria \\ ${ }^{2}$ Department of Botany, University of Calabar, Nigeria \\ ${ }^{3}$ Solaris Energy, Barbados Ltd, Barbados
}

\begin{abstract}
Akwa Ibom state is one of the nine states in the Niger Delta region of Nigeria. This region is critical to sustainable economic development in the country being the main oil producing area. With its location within the tropical rainforest and dense population, Uyo, like other major cities in Nigeria generates enormous municipal solid waste which is not adequately managed. Municipal solid waste management has therefore emerged as one of the greatest challenges facing environmental agencies in the city. Solid waste management is simply reduced to waste transfer with overflow dump sites causing serious environmental pollution. Waste management practices are characterized by inefficient collection and poor disposal methods. Waste stream comprises: $65 \%$ of compostable materials, $10 \%$ plastics, $8 \%$ paper, $4 \%$ metal, $3 \%$ textile, $3 \%$ glass and $7 \%$ others. The rate of waste generation ranged between 0.49 to $0.60 \mathrm{~kg} / \mathrm{capita} /$ day with an average of $0.54 \mathrm{~kg} / \mathrm{capita} / \mathrm{day}$. Inadequate finances, lack of institutional arrangement, insufficient information on the quantity and quality of waste as well as inappropriate technology are the main constraints militating against effective solid waste management in Uyo. The findings in this research are useful in formulating adequate waste disposal procedures. In addition, the potential of waste recovery, reduction and reuse based on waste characteristics is projected at about \$8million annually. However, further research is required in the area in order to maximize this potential.
\end{abstract}

Keywords: waste characterization, generation, recycle, reuse, reduce. 


\section{Introduction}

Municipal Waste (MW) generally comprises urban garbage produced from households, industries, commercial and institutional establishments (including hospitals), markets, yards and street sweepings. This waste will normally include; solid, liquid and gaseous materials which if allowed to accumulate will pollute the environment. With growing concerns on Climate Change and Global Warming, the need for effective waste management cannot be over emphasized.

In order to maintain a clean Municipal environment, urban waste must be effectively managed through appropriate reduction, reuse and/or recycled practices (Dauda and Osita [1]). Waste management generally involves the collection, transfer, treatment, recycling, resources recovery and disposal of waste in any location. The goals of waste management are therefore, to promote a quality environment, generate employment, and thus, support the efficiency and productivity of the economy.

The volume of waste being generated continues to increase at a faster rate than the ability of the agencies to improve on the financial and technical resources needed to parallel this growth. Waste management in Nigeria is generally characterized by inefficient collection methods, insufficient coverage of the collection system and improper disposal of waste materials (Eja et al. [2]). What to do with Municipal waste (trash) has long been a topic of heated discussion. For years, the answer had been to either burn it (incineration) or bury it (landfills), two processes with obvious serious environmental consequences. Thus, the management of municipal waste has emerged as one of the most serious problems facing environmental protection in developing countries. In most of these countries including Nigeria, Municipal Waste Management if carried out at all, involves just the collection and transfer of waste with little or no conversion practices. These actions have resulted in the transfer of waste from different collection centers to designated dump sites as is the case in Uyo. Consequently, urban areas are often defaced with heaps of garbage, a situation that has earned Nigerian cities the dirtiest in the world.

Agunwamda [3] observed that, the quantity of waste generated in urban areas in industrialized countries is higher than in developing countries, still municipal solid waste management remains inadequate in the latter. Also, waste in developing countries differs from developed countries. Most developing countries, example Nigeria, would therefore have waste management problems different from those found in developed countries in areas of composition, density, political and economic framework, waste amount, access to waste for collection, awareness and attitude. Ogwueleka [4] also reported that, waste is in developing countries is generally heavier, wetter and more corrosive.

While Uyo is emerging as one of the cleanest cities in Nigeria, the problems of waste management in this city are still far from being solved as waste is merely transferred from the main city to dump sites. The Ministry of Environment and Natural Resources is the only government agency responsible for waste management in Uyo. Although this Ministry has recorded some success in the area of waste collection and transfer but are still seriously lacking 
in the final phase of waste management which is waste utilization- converting waste into useful products such as energy. In addition, information on municipal solid waste management in Uyo is scanty. Eja et al. [5] however, reported on the impact of municipal solid waste on the environmental and public health in Uyo.

In order to formulate adequate solid waste utilization strategies, information on the amount, rate of generation as well as type of waste produced is critical. Such information is lacking in Uyo. This study is therefore, aimed at characterizing municipal solid waste in Uyo municipality with the view of formulating adequate waste utilization strategies.

\section{Materials and methods}

For the purpose of this investigation, Uyo Municipality was divided into four zones: North, South, East and West. A variety of waste characterization methods can be used to assess Municipal solid waste USEPA [6]. In the field investigation, sampling directly from waste generation points was adopted. Sampling was designed for two seasons: November to April, 2011 (dry season) and May to October, 2011 (wet season).

\subsection{Waste collection and transfer}

An assessment of the methods of waste collection and transfer was conducted by monitoring collection bins along major roads within the municipality. Also, the vehicles used for the transfer of waste from bins to dump sites were observed daily in order to evaluate the type of vehicles used, their working conditions as well as the regularity of transfer.

\subsection{Waste characterization}

Residential assessment was undertaken by sampling twenty (50) households per zone. Two different colour bins; one bin for rapidly biodegradable materials and the second for slowly biodegradable and non-biodegradable waste were provided. Bins were emptied daily. Sampling was also conducted for commercial areas (open markets, shopping complexes and hotels/restaurants). Three markets, shopping complexes and hotels each were sampled per zone. The total number of markets, shopping complexes and hotels was obtained from the Uyo Municipal Authority, and this was used in computing the total amount of waste generated.

With respect to institutional areas, three primary schools, three secondary schools and one university were sampled. Three healthcare centers and a hospital were also surveyed. The daily average waste generation per student (for educational institution) and per bed (for health) were evaluated. The total amount of MSW generated in institutional areas was estimated by computing the total number of educational institutions with students and healthcare centers/hospitals with beds within Uyo.

Waste from street sweepings was also assessed. The waste generated per $100 \mathrm{~m}$ of road length was determined by selecting ten paved roads ( $1 \mathrm{~km}$ each). The total length of paved roads in Uyo was obtained from the Municipal 
Authority and used in calculating the total amount of waste generated from street sweepings. Finally, the total MSW generated from residential, commercial and institutional areas as well as street sweeping was determined per zone and Uyo Municipal Area.

In the laboratory, the weight of collected waste samples was measured and then transferred for sorting. Portions of the waste were placed on sorting tables and sorting was carried out manually. Waste was categorized by adopting a modified method of AIT [7]. Waste was grouped into seven major categories namely: organic matter, paper, plastics, textiles, metals, glass and others.

\subsection{Resource recovery and recycling}

Four methods were adopted in evaluating the level of resource recovery and recycling in Uyo:

i) Interview of ten Ministry of Environment staff associated with waste management.

ii) Visits to dump sites to compare waste composition with those from bins.

iii) Evaluation of scavengers' recovery content

iv) Cost projections on recyclable and composting materials were also assessed.

\section{Results}

\subsection{Waste collection and transfer}

Solid waste in Uyo is collected in bins that are located along major streets (fig 1). The bin sizes range between 400 and $560 \mathrm{~kg}$ and are placed $1000 \mathrm{~m}$ $2000 \mathrm{~m}$ apart. Different types of vehicles are employed in the transfer of waste to dump sites. These include compactor trucks, tippers, pick-ups, side and rear loader and skip trucks. It was noted that most of these vehicles are in a state of disrepair and breakdown frequently. The efficiency of collection is quite low with less than $50 \%$ of generated solid waste actually conveyed to dump sites. The collection time is also irregular, thus waste accumulate in open dumps at road sides when the bins are full. Uyo has several designated dump sites which are often filled and now overflow (fig. 2).

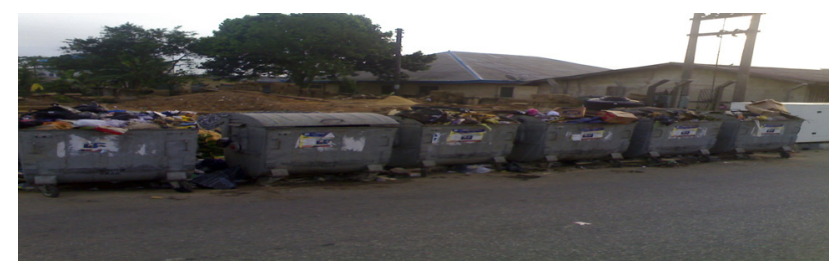

Figure 1: $\quad$ Waste bins on a major street in Uyo. 


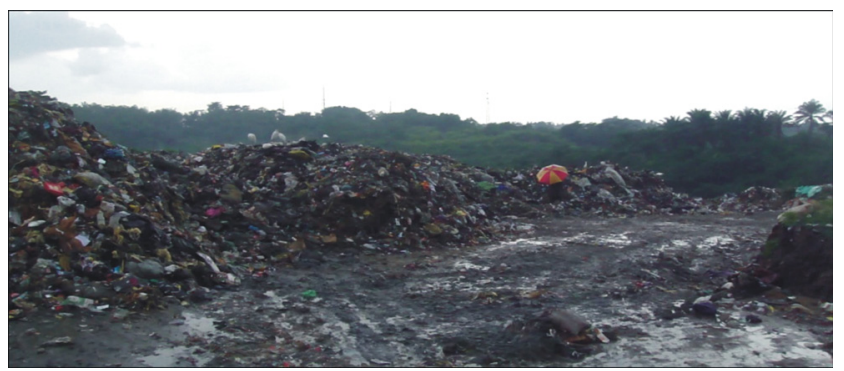

Figure 2: $\quad$ Dump site.

\subsection{Waste characterization}

\subsubsection{Waste generation}

A total of 420 tons of waste was generated per day (table 1). The highest amount of waste (273t) was generated in the Southern zone of the city while the least amount of 49 tons was produced in the Western zone. The Northern and Eastern zones generated $96 \mathrm{t}$ and $73 \mathrm{t}$ respectively (table 1 ). The waste generation rate per capita ranged between 0.48 and 0.61 with a weighted average of 0.54 (table 2).

Table 1: $\quad$ Component weight of MSW generated in four zones of Uyo.

\begin{tabular}{|c|c|c|c|c|c|}
\hline $\begin{array}{c}\text { Waste } \\
\text { components }\end{array}$ & \multicolumn{5}{|c|}{ Waste generation (tons/day) } \\
\hline & North & South & East & West & $\begin{array}{c}\text { All waste } \\
\text { streams }\end{array}$ \\
\hline Biodegradable & 64 & 150 & 40 & 19 & 273 \\
\hline Plastic & 10 & 15 & 10 & 7 & 42 \\
\hline Paper & 8 & 11 & 7 & 7 & 33 \\
\hline Metal & 3 & 10 & 3 & 1 & 17 \\
\hline Glass & 2 & 5 & 3 & 3 & 13 \\
\hline Textiles & 1 & 5 & 3 & 4 & 13 \\
\hline Others & 8 & 6 & 7 & 8 & 29 \\
\hline Total & 96 & 202 & 73 & 49 & 420 \\
\hline
\end{tabular}

Table 2: $\quad$ Waste generation rate (Kg/capita/day).

\begin{tabular}{|c|c|c|c|}
\hline Zones & Population & Amount $(\mathrm{t})$ & Kg/capita/day \\
\hline North & 200,000 & 96.0 & 0.48 \\
\hline South & 400,000 & 202.0 & 0.51 \\
\hline East & 130,000 & 73.0 & 0.56 \\
\hline West & 80,000 & 49.0 & 0.61 \\
\hline Total & $\mathbf{8 0 0 , 0 0 0}$ & $\mathbf{2 4 0 . 0}$ & $\mathbf{2 . 1 6}$ \\
\hline $\begin{array}{c}\text { Weighted } \\
\text { Average }\end{array}$ & - & - & 0.54 \\
\hline
\end{tabular}




\subsubsection{Waste composition}

Sixty five percent $(65 \%)$ of the total waste generated comprised biodegradable materials, fig. 3. The second largest percentage (10\%) was taken up by plastics, while metal and glass materials constituted 7\% combined. The remaining 7\% was made-up of others which included ceramics, rubber, soil, bones and dust.

\section{Chart Title}

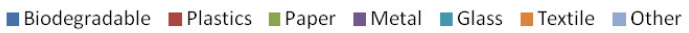

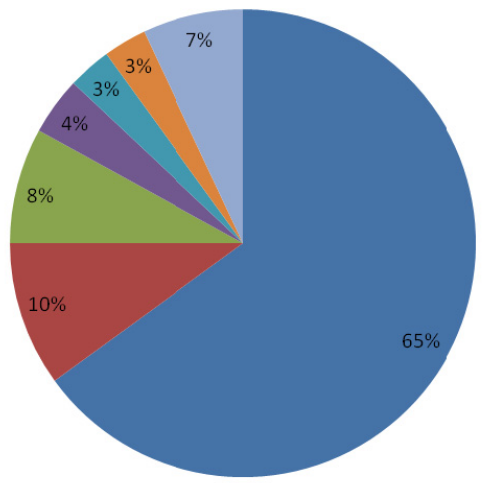

Figure 3: Waste composition.

\subsubsection{Contribution of different sources in total waste generation and waste disposal methods}

The highest amount of waste (67.5\%) was produced in the residential areas (table 3). Commercial areas followed with $28.3 \%$ while Institutions, street sweepings and others made up just $4.05 \%$. With respect to waste disposal methods, $60 \%$ of municipal solid waste was disposed through open dumping, while $20 \%$ was by land filling. Composting comprised $10 \%$, incineration $8 \%$ and 3R (Recover, Recycle, Reuse) just 2\% (fig. 4).

Table 3: $\quad$ Contributions of different sources in total waste generation (\%).

\begin{tabular}{|l|r|r|r|r|r|}
\hline Sources & \multicolumn{5}{|c|}{ MSW generation/day (\%) } \\
\hline & North & South & East & West & $\begin{array}{c}\text { All waste } \\
\text { streams }\end{array}$ \\
\hline Residential & 67.0 & 70.0 & 65.0 & 68.0 & 67.5 \\
\hline Commercial & 29.0 & 25.0 & 31.0 & 28.0 & 28.3 \\
\hline Industrial & 3.0 & 2.6 & 1.0 & 2.0 & 2.3 \\
\hline $\begin{array}{l}\text { Street } \\
\text { Sweeping }\end{array}$ & 0.8 & 2.0 & 2.9 & 1.7 & 1.5 \\
\hline Others & 0.2 & 0.4 & 0.1 & 0.3 & 0.3 \\
\hline Total & 100 & 100 & 100 & 100 & 100 \\
\hline
\end{tabular}




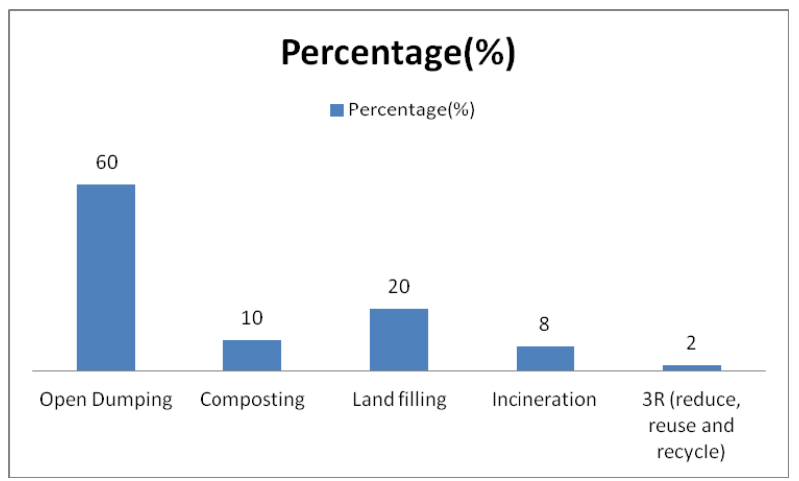

Figure 4: $\quad$ Percentage of waste disposal methods.

\subsubsection{Waste recovery}

There are no formal waste resource recovery/recycling programmes in Uyo. However, very limited recovery operations are undertaken by the informal sector such as scavengers (fig. 5).

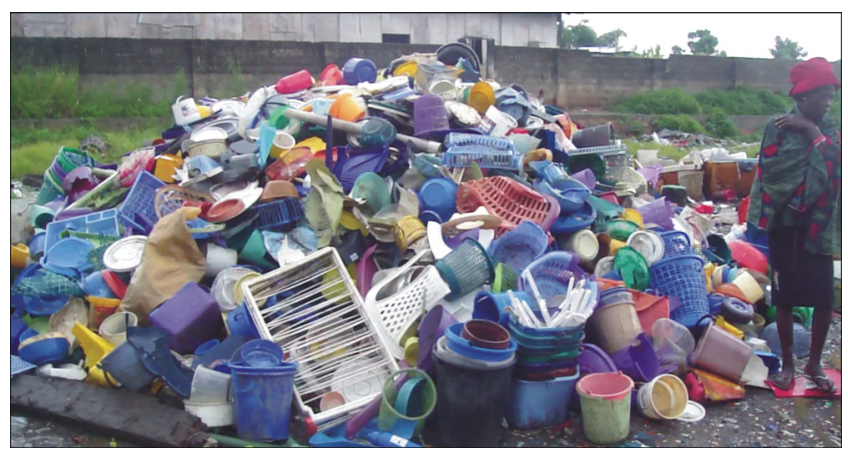

Figure 5: $\quad$ Sorted plastic materials.

Following assessments in this study, a total of 329t of waste can be recovered daily (table 4). Out of this total amount of recoverable items, 250t are of compostable materials while 36t are plastics. Twenty five tons of paper can also be recovered daily (table 4). In monetary terms, based on the 2010 price projections (US\$/t), \$21,548 can be generated daily (table 4).

\section{Discussions}

Waste Management in Uyo municipality is the full responsibility of the Ministry of Environment and Mineral Resources. Like other Government activities, the collection, transfer and utilization of waste is grossly inadequate. Poor funding, lack of expertise and manpower, use of obsolete technologies as well as lack of 
Table 4: $\quad$ MSW recoverable materials in Uyo.

\begin{tabular}{|l|r|r|r|r|}
\hline Items & \multicolumn{4}{|c|}{ Recoverable materials/cost } \\
\hline & $\begin{array}{c}\text { Total } \\
\text { weight }(\mathrm{t})\end{array}$ & $\begin{array}{c}\text { Recovery } \\
\text { weight }(\mathrm{t})\end{array}$ & $\begin{array}{c}\text { 2010 Price } \\
(\mathrm{US} \$ / \mathrm{t})\end{array}$ & $\begin{array}{c}\text { Market value } \\
(\mathrm{US} \$)\end{array}$ \\
\hline Plastic & 42.0 & 36.0 & 80.00 & $2,888.00$ \\
\hline Paper & 33.0 & 25.0 & 86.00 & $2,150.00$ \\
\hline Metal & 17.0 & 10.0 & 100.00 & $1,000.00$ \\
\hline Glass & 13.0 & 8.0 & 40.00 & 320.00 \\
\hline Textile & 13.0 & 7.0 & 20.00 & 140.00 \\
\hline Others & 29.0 & 5.0 & 10.00 & 50.00 \\
\hline Compostable & 273.0 & 250.0 & 60.00 & $15,000.00$ \\
\hline Total/day & 420.0 & 341.0 & - & $21,548.00$ \\
\hline Total/year & 153,300 & 122,640 & - & $7,865,020.00$ \\
\hline
\end{tabular}

data are the main constraints militating against proper waste management practices in Uyo. Waste is collected through bins which are placed too far apart for effective collection. Residents therefore find it difficult to travel long distances in order to place their waste in such bins. As a result, waste is dumped indiscriminately along bushes and uncompleted buildings. The transfer of waste is also problematic. Most of the vehicles used for this purpose required urgent servicing and the rate of transfer is also inconsistent. Consequently, bins are often filled and most times they over flow causing spillage of waste. This shows lack of commitment on the part of the Government in tackling environmental issues.

The findings in this study also indicate that a high percentage of the waste generated in uyo is of organic matter. Similar results have been reported in other Nigerian and Asian cities [4, 8, 9]. Waste generation rates are generally reported to be higher in urban centers, Alsamawi [10], hence, the weighted average of 0.54 could be considered low since Uyo is a capital city and one of the top oil producing areas in Nigeria. This low estimated value could be a reflection of poor collection and transfer methods adopted. The complex composition of municipal solid waste in Uyo is an indication of the consumption pattern of the inhabitants and the heterogeneity of the waste stream. This type of waste is difficult to incinerate and therefore require other means of disposal. Open dumping is the most popular method of waste disposal. This form of waste disposal is grossly inadequate and could result in environmental pollution and so should be discouraged. Land filling is also practiced but at a lower percentage and most landfills often overflow causing land pollution.

In Uyo as well as in most cities in Nigeria, there is no formal recycling of waste materials [11]. At the moment, recovery functions are carried out by informal sector such as the scavengers who manually sort out garbage and recover only limited items such as plastics (fig. 3). Recycling is a more environmentally friendly method of disposing waste and should be encouraged. It not only reduces the amount of waste to be collected and transferred but also generates income for government and individuals. Composting is another means 
of utilizing municipal solid waste. This is a natural biological process that can be conducted under controlled aerobic or anaerobic conditions. Although, composting is a useful solid waste recycling process, it requires effective mechanical sorting which is not yet adopted in Uyo. However, there are available sustainable technologies than can produce everything that we currently derive from crude oil (both fuels and petrochemicals) from a more renewable source: municipal solid waste [12]. This green energy source can be obtained from garbage dumps and landfills. Recyclable materials can also provide papers, plastics, metals and glass that can be used for purposes.

The assessment of recoverable materials in this study indicate that 329t of municipal solid waste can be recovered from the total of 420 t generated daily. Based on the 2010 price of recoverable items per ton, it is projected that about \$8m (eight million US\$) can be generated from recyclable materials. This amount could assist the Government in making Uyo cleaner and creating jobs for its inhabitants.

Although, there is increasing awareness on waste management in Nigeria, the findings of this study indicate that Municipal Solid Waste Management in Uyo is far from meeting WHO standards and suggest that effective waste management procedures be adopted. It is therefore recommended that Government should: hand over waste management to private agencies that will be more efficient and effective, put in place proper legislation and laws that will enable individuals and companies to comply and adhere to environmental safety regulations, provide adequate funding and adopt new technologies for effective waste management in Uyo municipality. These strategies should be extended to cover other parts of Akwa Ibom state.

\section{References}

[1] Dauda, M. and Osita, O.O., Solid waste management and reuse in Maiduguri, Nigeria. Proc. of the $29^{\text {th }}$ WEDC Int. Conf. towards the Millennium Development Goals, Abuja, pp. 30-36, 2003.

[2] Eja, M.E., Asikong, B.E. and Arikpo, G.E., Solid waste management in South Eastern Nigeria: A case study of Ogoja development Area, Tropical Environmental Research, 5, pp. 20-25, 2003.

[3] Agunwamba, J.C., Analysis of scavenger's activities and recycling in some cities of Nigeria, Environmental Management, 32(1), pp. 116-127.

[4] Ogwueleka, T.Ch., Municipal solid waste characteristics and management in Nigeria, Iran Journal of Environmental Health Science Engineering, 6(3), pp. 173-180.

[5] Eja, M.E., Alobi, N.O., Ikpeme, E.M., Ogri, O.R. and Inyang, A.O., Environmental and public health-related assessment of solid waste management in Uyo, Akwa Ibom State, Nigeria. World Journal of Applied Science and Technology, 2(1), pp. 110-123.

[6] United States Environmental Protection Agency (USEPA). Characterization of municipal solid waste in the United States, 1995 update, USEPA 530-R96. 
[7] Asian Institute of Technology (AIT), Sampling Techniques of municipal solid waste. School of Environment, Resource and Development, Thailand, EV. 04/11.

[8] Khajuria, A., Yamamoto, Y and Movioka, T., Estimation of municipal solid waste generation and landfill area in Asian developing countries. Journal of Environmental Biology, 31(5), pp. 649-654.

[9] Ministry of Forest, "Sustainable development study of urbanized areas", New Delhi, India.

[10] Alsamawi, A.A., and Zboon, A.R., Estimation of Bangladesh municipal solid waste generation rate. Engineering and Technology Journal, 29(1), pp. 131-140, 2009.

[11] Ogwueleka, T.C., Analysis of solid waste management and reuse in Maiduguri, Nigeria. Proc. of the $29^{\text {th }}$ WEDC Int. Conf. towards the Millennium Development Goals, Abuja, pp. 64-74.

[12] Mutui, G. and Nakamura, E., Bioconversion of ligno cellulosic waste from selected dumping sites in Dares Salam, Tanzania Biodegradation, 16(6), pp. 493-499. 